\title{
Permainan Musik Feeling Band Sebagai Strategi Peningkatan Sikap Sabar Anak Usia 4-5 Tahun
}

\author{
Akhtim Wahyuni ${ }^{\circledR}{ }^{\bowtie}$, Badriya Nur Safitri $^{2}$ \\ Manajemen Pendidikan Islam, Universitas Muhammadiyah Sidoarjo, Indonesia(1) \\ Pendidikan Guru Pendidikan Anak Usia Dini, Universitas Muhammadiyah Sidoarjo, \\ Indonesia(2) \\ DOI: $\underline{10.31004 / \text { obsesi.v6i3.1778 }}$
}

\begin{abstract}
Abstrak
Sabar merupakan sikap dasar emosional yang harus dilatih dan biasakan sejak dini. Anak yang sabar akan mampu menyelesaikan tanggung jawabnya dengan baik tanpa marah dan tergesa-gesa. Penelitian ini bertujuan untuk meningkatkan sikap sabar melalui permainan musik feeling band anak usia 4-5 tahun di RA Hasan Munadi I Banggle Beji, Pasuruan. Metode penelitian yang digunakan adalah Penelitian Tindakan Kelas model Kemmis dan Mc. Taggart dengan tahapan perencanaan, pelaksanaan, observasi, dan refleksi. Subyek tindakan berjumlah 13 anak. Kegiatan diawali Pra Siklus, selanjutnya proses penelitian menggunakan 2 tahap yaitu Siklus I dengan permainan musik dari botol plastik kosong dan diisi batu. Siklus II anak diajak memainkan alat musik dari kaleng, botol plastik diisi batu, gelas kaca, tutup botol, dan stick. Hasil penelitian menunjukkan, sikap sabar anak dari Pra Siklus, Siklus I, dan Siklus II mengalami peningatan signifikan. Ini membuktikan adanya peningkatan sikap sabar anak setelah dilakukan permainan musik feeling band.
\end{abstract}

Kata Kunci: sikap sabar; anak usia dini; permainan musik feeling band

\begin{abstract}
Patience is an emotional fundamental attitude which needs to be learned and employed from an early age. Without being upset or hurried, a patient child will be able to do his or her job effectively. This study aims to increase patience through a music game called feeling band. It is designed for children aged 4-5 years at RA Hasan Munadi I Bangle, Beji Pasuruan. The research method used is a Classroom Action Research model by Kemmis and Mc. Taggart with stages of planning, implementation, observation, and reflection. The subjects of the action totaling 13 children. Activities began with pre-cycle, furthermore, the research process used 2 stages, namely Cycle I with music playing from plastic bottles filled with stones. Cycle II, children were invited to played musical instruments from cans, plastic bottles filled with stones, glass cups, and sticks. The instrument was played alternately according to the rules. The results showed that the patience of children from pre-cycle, first cycle, and second cycle experienced a significant increase. This proves that there is an increase in the child's patience after being treated through music game, feeling band.
\end{abstract}

Keywords: patience; early childhood; feeling band musik games

Copyright (c) 2021 Akhtim Wahyuni, Badriya Nur Safitri

$\triangle$ Corresponding author:

Email Address : awahyuni@umsida. ac. id (Sidoarjo, Jawa Timur, Indonesia)

Received 27 May 2021, Accepted 19 September 2021, Published 22 September 2021 


\section{PENDAHULUAN}

National Association for the Education Young Children (NAECY) menyatakan bahwa anak usia dini atau "early childhood" merupakan anak yang berada pada usia nol sampai dengan delapan tahun (Suyanto, 2017). Pada masa tersebut merupakan proses pertumbuhan dan perkembangan dalam berbagai aspek pada berbagai rentang usia manusia. Maka proses pembelajaran terhadap anak harus memerhatikan karakteristik yang dimiliki dalam tahap perkembangan anak (Allen \& Lalonde, 2020).

Penanganan anak usia dini, khususnya dalam bidang pendidikan sangat menentukan kualitas pendidikan bangsa di masa mendatang. Pada usia ini, kualitas hidup anak memiliki makna dan pengaruh yang luar biasa untuk kehidupan selanjutnya (Buroidah et al., 2021). Oleh karena itu, masa perkembangan anak pada usia tersebut sebagai 'the golden age' harus dioptimalkan seluruh potensinya, termasuk perkembangan emosionalnya.

Perkembangan emosional mencakup semua kemampuan anak untuk mempertalikan, berkomunikasi, dan berinteraksi dengan dunia (Bates, 2019). Termasuk kemampuan untuk menyatakan perasaan, seperti rasa sayang, marah, suka, puas, senang, sabar, dan percaya (Fachrurrazi, 2012). Orang tua, pendidik, dan orang dewasa lainnya mempunyai tugas melatih anak untuk belajar mengendalikan emosi anak agar bisa melampiaskan emosinya dengan cara-cara yang benar dan baik (Piquer et al., 2020). Hal ini karena semua pengalaman emosi yang didapat di masa kanak-kanak ikut berperan penting mempengaruhi sirkuit emosi penentu di masa yang akan datang. Seseorang akan mampu mengolah dan mengelola emosinya dengan tepat jika orang tersebut mendapatkan latihan-latihan emosi yang tepat di masa kecilnya. Sebaliknya, jika sejak kecil tidak mendapatkan latihan-latihan emosi yang tepat, maka akan mendapatkan kesulitan dalam menghadapi permasalahan hidup di masa mendatang (Bateman, 2020).

Sabar merupakan sikap dasar emosional yang harus dilatih dan biasakan sejak dini. Ia berasal dari istilah bahasa Arab, dan sudah menjadi istilah dalam bahasa Indonesia, asal katanya 'shabara', yang membentuk infinitif menjadi 'shabran'. Dari segi bahasa, sabar berarti menahan dan mencegah"(Bambang, 2008). Anak yang memiliki sikap sabar tidak lekas marah, tidak lekas putus asa, tidak lekas patah hati, tabah, tenang, tidak tergesa-gesa, tidak terburu nafsu (Vuorinen et al., 2021). Sabar adalah suatu potret kestabilan jiwa yang ditandai oleh kemampuan orang untuk mengendalikan diri, lebih mengutamakan pikiran dari pada perasaan (Tholee, 2017). Kestabilan emosi ini juga terlihat dari cara mereka bereaksi terhadap setiap permasalahan, tidak reaktif dan tidak meledak-ledak. Indikator yang paling sederhana dari sebuah kesabaran adalah tidak mudah marah dan tergesa-gesa (Suyadi, 2010).

Supeni senada dengan yang disampaikan Suyadi bahwa anak yang sabar akan mampu menyelesaikan masalahnya atau tanggung jawabnya dengan baik tanpa marah dan tanpa tergesa-gesa (Supeni et al., 2019). Sehingga setiap permasalahan atau tanggung jawab yang dihadapi akan terselesaikan dengan baik pula. Anak yang mampu menyelesaikan sebuah permsalahannya dengan cermat, maka anak dapat dikatakan sabar atau dapat mengendalikan emosinya.

Di dalam kompetensi dasar 2.7, "memiliki perilaku yang mencerminkan sikap sabar (mau menunggu giliran, mau mendengarkan dengan baik ketika orang lain berbicara) untuk melatih kedisiplinan merupakan kompetensi yang harus dicapai anak. Sikap sabar terlihat pada perilaku anak yang mampu menahan diri, bersikap tenang, tidak lekas marah dan menunda keinginan, sikap mau menunggu giliran, mau mendengarkan ketika orang lain berbicara, tidak menangis saat berpisah dengan ibunya, tidak mudah mengeluh, tidak tergesa-gesa, selalu menyelesaikan tugasnya hingga tuntas, dan berusaha tidak menyakiti atau membalas dengan kekerasan (Pembinaan AUD, 2015).

Hasil observasi sikap sabar anak di RA Hasan Munadi I Banggle Kecamatan Beji Pasuruan sebagaimana pada tabel 1, diperoleh data sejumlah 11 anak dari jumlah total 13 anak belum memiliki sikap sabar, sedangkan 2 anak sudah memiliki sikap tersebut. 


\section{Tabel 1. Sikap Sabar Anak}

\begin{tabular}{ccc}
\hline Jumlah Anak & Memiliki Sikap Sabar & Belum memiliki Sikap sabar \\
\hline 13 Anak & 2 anak & 11 anak \\
\hline
\end{tabular}

Hal yang tampak dalam keseharian saat pembelajaran diantaranya; anak kurang memperhatikan guru, susah menunggu giliran, dan tugas yang dikerjakan seringkali tidak tuntas. Dalam mengatasi hal tersebut, guru telah melakukan upaya-upaya perbaikan dalam pembelajaran. Namun, pembelajaran tentang moral yang dilakukan melalui cerita, dongeng, dan demonstrasi belum dapat merubah sikap sabar anak. Maka kondisi tersebut menjadi dasar perlunya dilakukan perubahan stimulasi baru untuk mengajarkan anak didik bersikap sabar.

Permainan menjadi pilihan dalam meningkatkan sikap sabar anak. Hasil penelitian Pakerti dan Widia menunjukkan bahwa melalui permainan, anak mempelajari berbagai keterampilan motorik, keterampilan bersosialisasi, sekaligus memperoleh kesenangan dan hiburan (Pakerti, Widia, 2009). Anak-anak dan aktivitas bermain merupakan dua subjek yang telah menyatu dalam satu kesatuan yang tidak dapat dipisahkan. Dalam kegembiraan bermain, berpetualang dan mengeksplorasi lingkungan, anak-anak juga tengah mengembangkan berbagai jenis kecerdasan dan mempraktikan beragam keterampilan hidup yang sangat berguna bagi kehidupan mereka kelak (Chae et al., 2020). Permainan musik bisa digolongkan dalam bermain aktif bila anak melakukan kegiatan bermain musik seperti benyanyi, memainkan alat musik atau melakukan gerakan-gerakan atau tarian yang diiringi musik (Priyanti, Iin dan Setyowati, 2015). Melalui permainan musik yang dimainkan bersama teman dapat mengajarkan anak untuk bekerjasama dengan baik (M, Forgeard., E, Winner., $A$, Norton., G, 2008).

Manfaat bermain musik bagi anak diantaranya adalah: (1) Anak dapat mengikuti peraturan permainan. (2) dapat mengendalikan emosi. (3) Meningkatkan kecerdasan emosional dengan mengendalikan diri pada saat bernyanyi atau memainkan alat musik agar diperoleh kesatuan bunyi yang teratur atau kekompakan dalam membunyikan nada yang beraturan sehingga enak didengar (4) Meningkatkan kemampuan gerak karena musik mampu merangsang gerak, sebaliknya gerak pun dapat menghasilkan bunyi (5) Meningkatkan kreativitas, bila pembelajaran memberi kesempatan anak untuk merespon, membuat tanggapan dan mencipta sesuai imajinasi dan konsep yang dimiliki anak. Kreativitas musik akan memacu kreativitas bidang lain dengan sendirinya (6) Membantu meningkatkan berbagai kecerdasan, antara lain kecerdasan berfikir logis dan berfikir matematis, karena musik dalam hal tertentu memiliki keteraturan (Dwi Wardhani, 2016).

Achroni juga menyatakan bahwa memainkan alat musik dan membuat alat musik memiliki manfaat; (1) Memberikan kegembiraan pada anak, (2) Mengasah kreativitas anak. (3) Melatih motorik halus anak, (4) Melatih ketekunan dan kesabaran anak, (5) Mengasah kepekaan anak akan musik (mengasah kecerdasan musikal anak), (6) Melatih kerjasama anak dengan teman-temannya dan sebagai media untuk bersosialisasi, (7) Mendekatkan anak pada alam (mengasah kecerdasan naturalis anak), (8) Melatih anak untuk berhemat dengan mengurangi pengeluaran untuk membeli mainan (Achroni, 2012).

Alat musik yang digunakan tidak harus membeli, akan tetapi dapat memanfaatkan limbah di sekitar lingkungan anak untuk mengimitasi alat-alat musik yang dapat digunakan sebagai alat musik dasar sederhana, seperti: botol plastik bekas, tabung kaleng bekas, gelas, galon, botol kaca, tutup botol bekas, sendok, potongan pipa paralon, dan lain sebagainya. Masih banyak lagi pengimitasian alat musik yang dapat dibuat dengan menggunakan limbah yang tidak berbahaya bagi anak di sekitar lingkungan anak. Alat musik imitasi tersebut dapat digunakan sebagai alat musik ritmik pengiring yang dimainkan oleh anak-anak secara bersama-sama. Anak-anak akan memperoleh pengalaman dalam mengkonstruksi dan mendekorasi alat-alat musik tersebut (Supeni et al., 2019). 
Permainan musik yang diterapkan pada penelitian ini adalah permainan sederhana dan cara memainkannya disesuaikan karakteristik alat masing-masing. Misalnya dikocok, dipukul, dipetik atau ditekan. Dalam permainan musik tersebut ada peraturan yang harus diikuti oleh pemain agar mendapatkan nada yang beraturan dan enak didengar. Memainkan musik secara estetis dan terlibat dalam aktivitas musik memengaruhi perkembangan emosional anak. Perubahan perkembangan di bidang emosi terkait dengan ekspresivitas, kontrol keadaan emosi sendiri, dan mengenal emosi diri sendiri dan orang lain. Perkembangan emosi hanya dapat berlangsung dalam kontak sosial dengan orang lain, dalam kegiatan bersama. Anak-anak merasa paling mudah untuk mengidentifikasi kegembiraan, kesedihan, kemarahan dan ketakutan (Harun et al., 2020)

Penelitian tentang permainan musik Feeling Band dilakukan oleh Wahyuni tentang peningkatan kemampuan mengekspresikan emosi dasar melalui permainan musik feeling band' menunjukkan hasil yang signifikan yaitu dari pra Siklus (44,69\%), Siklus I (59,69\%)dan Siklus II (78,44\%) (Wahyuni, 2014). Penelitian Supeni juga menghasilkan, melalui suatu permainan musik anak memiliki suatu kesenangan dan hiburan tersendiri (Supeni et al., 2020) Dalam permainan musik ini anak diajarkan untuk bersabar agar mendapatkan suatu nada yang beraturan dan enak didengar.

Melihat manfaat permainan musik sebagaimana tergambar di atas, maka untuk mengatasi masalah sikap sabar anak di RA Hasan Munadi I Banggle Kecamatan Beji Pasuruan, dilakukan Penelitian Tindakan Kelas 'Permainan Musik Feeling Band sebagai strategi peningkatan sikap sabar anak. Dengan demikian, penelitian ini memperkaya referensi tentang manfaat permainan musik Feeling Band pada anak dan memberikan alternatif solusi dalam meningkatkan sikap sabar anak usia dini melalui kegiatan rekreatif dan menyenangkan sesuai karakteristik anak.

\section{METODOLOGI}

Penelitian ini dilaksanakan di RA Hasan Munadi I Banggle Kecamatan Beji Pasuruan dengan subyek penelitiannya anak usia 4-5 tahun, sejumlah 13 anak. Rancangan penelitian menggunakan Penelitian Tindakan Kelas (PTK) mengacu pada model Kemmis dan Mc. Taggart (Sanjaya, 2011), dengan empat tahapan yaitu: perencanaan (planning), tindakan (acting), observasi (observing), dan refleksi (reflecting). Penelitian ini dilakukan selama dua bulan mulai bulan Maret-April 2020, menerapkan 2 Siklus.

Ada dua jenis data yang didapatkan dalam penelitian ini; data kualitatif dan kuantitatif. Data kualitatif diperoleh dari aktivitas anak dan aktivitas guru berupa hasil observasi dan wawancara. Sedangkan data kuantitatif diperoleh dari hasil pembelajaran yang diberikan kepada siswa.

Teknik pengumpulan data menggunakan teknik observasi, wawancara, dan dokumentasi. Observasi dilakukan untuk mengetahui proses pembelajaran dengan permainan feeling band untuk meningkatkan sikap sabar anak. Pedoman observasi pada penelitian ini dititikberatkan pada pengamatan aspek-aspek sikap sabar anak selama pelaksanaan proses pembelajaran. Data observasi dilengkapi dengan format atau blangko pengamatan dan penilaian aktivitas anak dan guru. Sebelum digunakan di lapangan, seluruh instrumen pengumpulan data divalidasi oleh 2 expert sesuai bidangnya. Hasil final validasi selanjutnya digunakan untuk menggali data di lapangan. Tabel 2 adalah indikator sikap sabar anak yang digunakan dalam penelitian.

Tabel 2 Indikator Sikap Sabar Anak

\begin{tabular}{ll}
\hline Aspek Penilaian & \multicolumn{1}{c}{ Indikator Penilaian } \\
\hline & $\begin{array}{l}\text { Anak mampu mengikuti petunjuk permainan dengan baik } \\
\text { Anak mampu menyelesaikan tugasnya atau tanggung jawabnya dengan } \\
\text { Sikap Sabar Anak } \\
\end{array}$ \\
& $\begin{array}{l}\text { cara tidak tergesa-gesa } \\
\text { Anak Sabar menunggu giliran }\end{array}$ \\
\hline
\end{tabular}




\section{HASIL DAN PEMBAHASAN}

Hasil

Penyajian hasil penelitian mengacu pada rancangan penelitian dengan tahapan: Pra Siklus, Siklus I, dan Siklus II. Hasil penelitian menunjukkan perbedaan pada pra Siklus, Siklus 1 dan Siklus II. Pada Pra Siklus rata-rata ketuntasan anak sebesar 41,0\%, Siklus I rata-rata ketuntsan anak sebesar $63,5 \%$, dan pada Siklus II rata-rata ketuntasan anak sebesar $85,3 \%$, Hal ini membuktikan adanya peningkatan sikap sabar anak secara signifikan, setelah dilakukan pembelajaran sikap sabar melalui permainan musik feeling band. Pada tabel 3 tergambar rekapitulasi perolehan nilai dari penerapan permainan musik feeling band dalam meningkatkan sikap sabar anak dari pra Siklus, Siklus 1, dan Siklus II.

Tabel 3 Data Pra Siklus, Siklus 1, dan Siklus II Sikap Sabar Anak

\begin{tabular}{clrrr}
\hline \multirow{2}{*}{ No } & \multirow{2}{*}{ Nama } & \multicolumn{3}{c}{ Prosentase Sikap Sabar (\%) } \\
& & Pra Siklus & \multicolumn{1}{c}{ Siklus 1 } & \multicolumn{2}{c}{ Siklus 2 } \\
\hline 1 & AF & 41.7 & 58.3 & 75.0 \\
2 & ACT & 50.0 & 66.7 & 83.3 \\
3 & AM & 33.3 & 75.0 & 91.7 \\
4 & CNJ & 41.7 & 75.0 & 75.0 \\
5 & MTL & 25.0 & 58.3 & 91.7 \\
6 & MRK & 41.7 & 58.3 & 83.3 \\
7 & MHB & 25.0 & 50.0 & 91.7 \\
8 & MRM & 41.7 & 58.3 & 83.3 \\
9 & NA & 58.3 & 75.0 & 100.0 \\
10 & PW & 58.3 & 75.0 & 100.0 \\
11 & RNS & 41.7 & 66.7 & 91.7 \\
12 & TS & 41.7 & 58.3 & 75.0 \\
13 & TAH & 33.3 & 50.0 & 66.7 \\
\hline \multicolumn{7}{c}{ Rata-rata } & 41.0 & 63.5 & 85.3 \\
\hline
\end{tabular}

Hasil data pada tabel 3 di atas selanjutnya dilakukan uji normalitas data yang hasilnya dapat dilihat pada tabel 4.

\section{Tabel 4 Tests of Normality}

\begin{tabular}{|c|c|c|c|c|c|c|c|}
\hline & \multirow[t]{2}{*}{ Siklus } & \multicolumn{3}{|c|}{ Kolmogorov-Smirnova } & \multicolumn{3}{|c|}{ Shapiro-Wilk } \\
\hline & & Statistic & $\mathrm{df}$ & Sig. & Statistic & $\mathrm{df}$ & Sig. \\
\hline \multirow{3}{*}{ Sikap Sabar } & Pra Siklus & .244 & 13 & .034 & .900 & 13 & .134 \\
\hline & Siklus 1 & .248 & 13 & .028 & .856 & 13 & .034 \\
\hline & Siklus 2 & .196 & 13 & .185 & .931 & 13 & .350 \\
\hline
\end{tabular}

a. Lilliefors Significance Correction

Berdasarkan nilai signifikan pada tabel 4 tes normalitas dapat diketahui bahwa nilai signifikan $>0,05$, sehingga dapat disimpulkan bahwa data pada pra Siklus, Siklus 1 dan Siklus 2 terdistribusi normal. Selanjutnya dilakukan uji paired sample t-test untuk melihat apakah ada perbedaan rata-rata antara pra Siklus dan Siklus 1. Hasil uji test dapat dilihat pada tabel 5 .

Berdasarkan tabel 5 nilai sig value $0.000<0.05$ sehingga dapat disimpulkan bahwa terdapat perbedaan antara nilai sikap pada pra Siklus dan Siklus 1 atau dengan kata lain Penerapan Permainan Musik Feeling Band berpengaruh terhadap Sikap Sabar Anak. Selanjutnya dilakukan uji sample paired sample $t$ test untuk melihat perbandingan data Siklus 1 dan Siklus 2. 
Tabel 5 Paired Samples Test

\begin{tabular}{|c|c|c|c|c|c|c|c|c|}
\hline & \multicolumn{5}{|c|}{ Paired Differences } & \multirow[t]{3}{*}{$t$} & \multirow[t]{3}{*}{$\mathrm{df}$} & \multirow{3}{*}{$\begin{array}{l}\text { Sig. }(2- \\
\text { tailed })\end{array}$} \\
\hline & \multirow[t]{2}{*}{ Mean } & \multirow[t]{2}{*}{$\begin{array}{c}\text { Std. } \\
\text { Deviation }\end{array}$} & \multirow[t]{2}{*}{$\begin{array}{l}\text { Std. Error } \\
\text { Mean }\end{array}$} & \multicolumn{2}{|c|}{$\begin{array}{l}\text { 95\% Confidence } \\
\text { Interval of the } \\
\text { Difference }\end{array}$} & & & \\
\hline & & & & Lower & Upper & & & \\
\hline $\begin{array}{ll}\text { Pair } & \text { Pra Siklus } \\
1 & \text { Siklus } 1\end{array}$ & $\begin{array}{r}- \\
22.423 \\
1\end{array}$ & 8.6030 & 2.3860 & -27.6218 & -17.2243 & -9.398 & 12 & .000 \\
\hline
\end{tabular}

\section{Hasil Uji Paired Sample t-test antara Siklus 1 dan Siklus 2}

Berdasarkan tabel 6 nilai sig value $0.000<0.05$ sehingga dapat disimpulkan bahwa terdapat perbedaan antara nilai sikap pada Siklus 1 dan Siklus 2 atau dengan kata lain Penerapan Permainan Musik Feeling Band berpengaruh terhadap Sikap Sabar Anak. Gambar 1 adalah grafik hasil nilai ketuntasan sikap sabar anak pada pra Siklus, Siklus I, dan Siklus II.

Tabel 6 Paired Samples Test
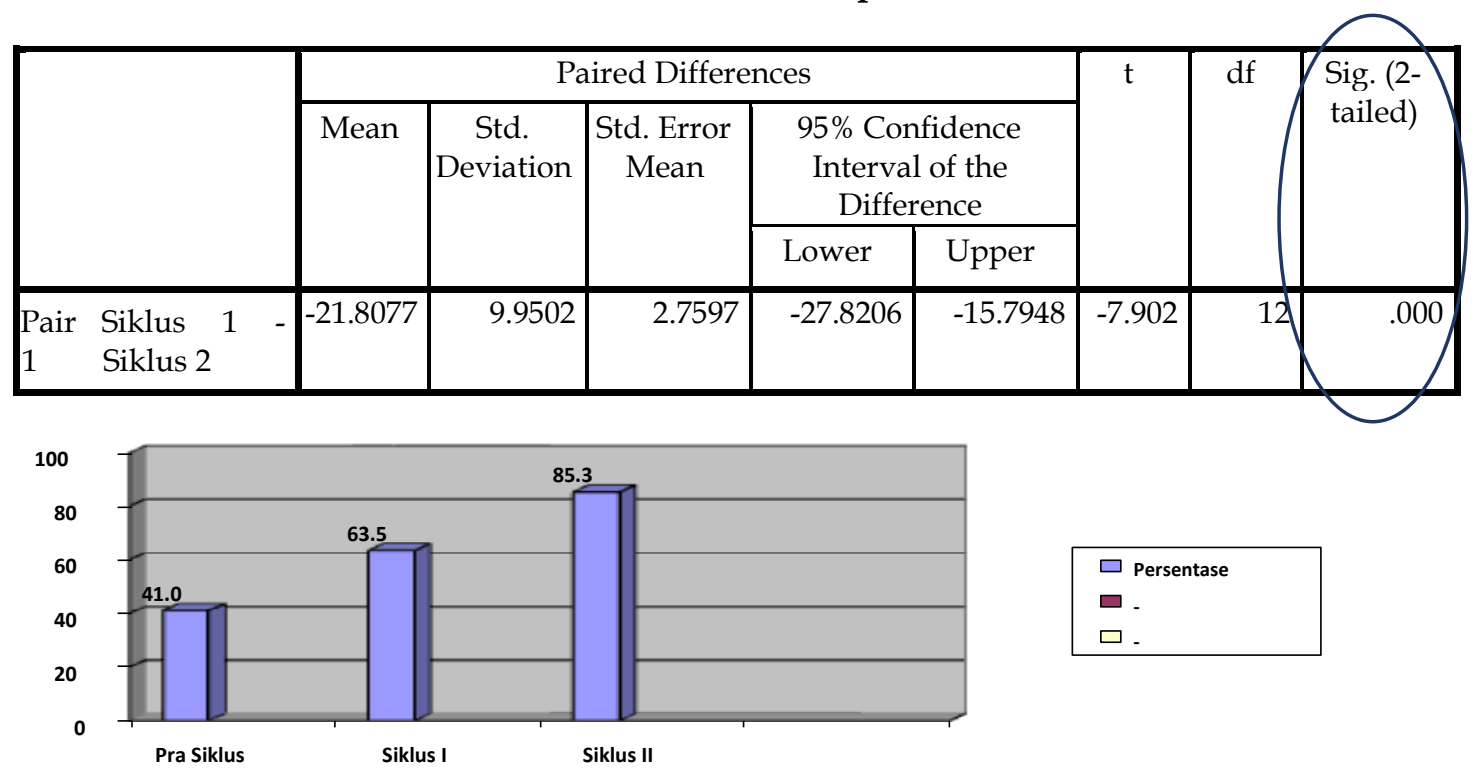

Gambar 1 Grafik Hasil Nilai Ketuntasan Peningkatan Sikap Sabar Anak Pada Pra Siklus, Siklus I dan Siklus II

Perbandingan sikap sabar anak melalui permainan musik feeling band yang dilakukan pada setiap tahap terjadi peningkatan perbandingan antara kemampuan anak sebelum dan sesudah tindakan. Peningkatan cukup signifikan dan melebihi indikator keberhasilan yang ditetapkan sebelum penelitian berlangsung sebesar 41,0\%. Penelitian ini dapat dikatakan berhasil karena anak sudah melebih indikator keberhasilan sebesar 75\%. Dapat dinyatakan bahwa permainan musik feeling band mampu meningkatkan sikap sabar anak usia 4-5 tahun di RA Hasan Munadi I Banggle Kecamatan Beji Pasuruan.

\section{Pembahasan}

Berdasarkan penyajian data yang telah dideskripsikan di atas, ada beberapa temuan penelitian yang perlu dibahas lebih lanjut. Temuan tersebut antara lain peningkatan sikap sabar mulai Pra Siklus, Siklus 1 dan Siklus II. Pada Pra Siklus 41, 0\% mengalami peningkatan di Siklus I rata-rata ketuntasan anak sebesar 63,5\%, dan pada Siklus II rata-rata ketuntasan 
anak sebesar 85,3\%. Hal ini membuktikan adanya peningkatan sikap sabar anak secara signifikan, setelah dilakukan pembelajaran permainan musik feeling band. Peningkatan hasil tindakan tidak lepas dari rancangan pembelajaran pada setiap Siklus yang peneliti lakukan. Siklus 1 dilakukan sesuai tahapan pada Rencana Program Pembelajaran Harian (RPPH) yang sudah dirancang. Tahapan pembelajaran diawali dengan kegiatan pembuka sebelum pembelajaran, kemudian dilanjut kegiatan inti, dan penutup. Pada kegiatan pembuka, anakanak duduk melingkar yang lazim disebut circle time. Anak diajak berdo`a, mengucap 2 kalimat syahadat, dan membaca surat-surat pendek. Guru menyiapkan alat musik yang diterapkan dalam pembelajaran anak-anak. Guru memulai pembelajaran dengan bercakapcakap terlebih dahulu. Setelah bercakap-cakap guru memberikan contoh cara memainkan alat musik yang akan dilakukan oleh anak-anak. Kemudian anak-anak menirukan seperti apa yang telah dilakukan oleh guru. Anak menirukan permainan musik feeling band dengan memainkan botol plastik diisi batu dan botol plastik tanpa diisi batu. Guru mengajak anak untuk memainkan alat musik tersebut dengan membunyikan nada sederhana dipadu dengan nada tepuk anak shaleh secara bersama-sama. Anak memainkan alat musik sesuai petunjuk guru. Setelah selesai semua, guru menutup pembelajaran bermain musik feeling band.

Dari pemberian tindakan Siklus 1 belum menghasilkan peningkatan sebagaimana target indikator keberhasilan penelitian. Hasil refleksi yang dilakukan bersama guru pamong, anak merasa bosan karena irama musik yang dihasilkan tidak variatif dan tidak menimbulkan bunyi yang beraturan. Nada yang dimainkan juga terlalu rancak sehingga menjadikan anak susah konsentrasi. Kondisi ini menjadikan target tindakan tidak tercapai, karena anak-anak belum bisa mengontrol diri untuk sabar menunggu giliran memainkan alat musiknya, mendengar petunjuk dengan baik, dan masih tergesa-gesa dalam melakukan kegiatan. Ketidakefektifan pembelajaran juga disebakan permainan musik feeling band dilakukan seluruh anak secara bersamaan sehingga pengelolaannya tidak maksimal.

Pada Siklus II tahapan penelitian dilakukan sebagaimana Siklus 1, dimulai kegiatan pembuka, inti dan penutup. Pada kegiatan inti peneliti melakukan perubahan dengan cara mengelompokkan anak-anak menjadi 2 kelompok dengan anggota 6 anak dan 7 anak. Aturan bermain pada Siklus ini juga lebih dikuatkan, agar anak-anak bisa memainkan alat musik dengan baik dan memiliki dampak positif pada sikap sabar mereka. Jenis nada yang dimainkan juga dipilih nada yang bisa menggugah ekspresi dan perasaan anak. Pada Siklus II ini anak diajak bermain musik feeling band dengan menggunakan alat musik berupa botol bekas diisi batu, kaleng biskuit bekas, botol kaca dan stick secara bergantian, dan tutup botol yang dirangkai menjadi kecrek. Dari ragam alat musik yang digunakan menjadikan anak lebih termotivasi dan senang memainkannya karena bunyi yang dihasilkan lebih berwarna. Anak-anak dapat membunyikan alat musik sesuai keingingan mereka dengan dipandu guru pada awalnya, namun akhirnya mereka bisa memainkannya sendiri secara bergantian sebagaimana aturan main yang sudah diberikan di awal. Proses ini menjadikan anak memahami bahwa dalam memainkan alat musik harus sesuai aturan main yang disampaikan guru dengan bergantian memainkannya agar menimbulkan bunyi yang indah dan berwarna. Melalui proses ini mereka belajar mendengar dengan baik petunjuk guru, mengasah sikap sabar dengan menunggu giliran memainkan alat musiknya, dan belajar untuk tidak tergesagesa. Selanjutnya proses ini dapat diterapkan dalam segala aktivitas anak, sehingga sikap sabar menjadi behavior dan budaya dalam hidup sehari-hari.

Sebagaimana hasil penelitian Meissner dan Timmers, bahwa permainan musik dalam dunia anak usia dini adalah salah satu wahana kegiatan belajar anak yang dapat mengasah perkembangan sosial emosional anak dan perkembangan gerak anak dalam memainkan alat musik (Meissner \& Timmers, 2020). Penguasaan tentang pengetahuan dasar dan keterampilan musik merupakan bagian yang tidak bisa terpisahkan dari proses pendidikan di Taman Kanak-kanak (TK) yang hampir di setiap kegiatannya memanfaatkan nyanyian dan permainan musik. Pendidik anak usia dini perlu mempelajari materi musik agar dapat memilih lagu dan memainkan alat musik yang cocok untuk diajarkan kepada anak didiknya, 
sehingga dapat menumbuhkan dan mengembangkan rasa estetika, musikalitas, dan rasa kebersamaan anak-anak (Kamtini, 2005). Penggunaan musik kepada anak tentu akan membawa dampak positif bagi proses pembelajarannya. Hal ini dikarenakan musik merupakan salah satu cara untuk merangsang pikiran, sehingga anak dapat menerima materi dengan baik. Selain itu dengan musik akan memperbaiki konsentrasi, ingatan, meningkatkan aspek kognitif, fisiologis dan juga kecerdasan emosional. Musik juga akan mempengaruhi perasaan anak yang akan berpengaruh pada proses belajar mengajar (Hasiana \& Wirastania, 2017).

Pemanfaatan musik dalam pembelajaran dapat membuat proses belajar menjadi menyenangkan. Sebagian besar anak di dunia senang mendengarkan musik. begitu mendengar musik, anak pada umumnya akan menggerakkan badannya mengikuti irama musik. Anak menjadi tertarik dan tidak bosan dalam belajar (Treacy \& Westerlund, 2019). Anak-anak pada umumnya mengagumi bunyi yang keluar dari instrumen-instrumen musik, baik instrumen tradisional ataupun yang non tradisional (M, Forgeard., E, Winner., A, Norton., G, 2008). Namun tidak semua instrumen musik cocok untuk digunakan di TK, jenis instrumen musik yang paling sesuai adalah jenis instrumen perkusi sederhana, seperti tamborin, kastanyet, triangel, berbagai jenis dan ukuran drum, marakas atau gong (Pakerti, Widia, 2009).

Keberhasilan penelitian ini juga sejalan dengan teori yang dikemukakan oleh Newcomb dalam Ali Nugraha (2014), permainan feeling band atau band perasaan adalah permainan membunyikan instrumen musik sesuai dengan ekspresi perasaan. Ada beberapa manfaat dari permainan feeling band yaitu diantaranya, permainan feeling band ini sangat membantu anak untuk melakukan proses katarsis, membantu anak dalam menyadari perasaannya sendiri dan belajar megontrol emosinya serta membantu anak untuk bersenangsenang (Przybylska, Anna., 2018). Selain itu, dinyatakan juga oleh May bahwa permainan musik dengan alat yang beragam dalam pembelajaran di kelas menjadikan anak lebih mampu mengeksplorasi banyak hal, baik sikap maupun perasaan. Anak dapat mengekspresikan perasaannya seperti rasa marah, sedih, senang, sabar, dan takut dengan memukul-mukul alat musik tersebut sesuai dengan perasaannya (Nixon May, 2013). Hasil penelitian ini didapatkan temuan baru yang memperkaya penelitian sebelumnya, bahwa permainan musik feeling band efektif untuk meningkatkan sikap sabar anak. Penelitian lanjutan dapat dikembangkan pada efektivitas permainan musik feeling band dalam mengatasi problem emosi anak, misal; peningkatan sikap peduli, empati, dan lainnya.

\section{SIMPULAN}

Sikap sabar anak usia 4-5 tahun di RA Hasan Munadi Banggle Pasuruan melalui permainan musik feeling band meningkat signifikan. Hasil ini didapat dari lembar penilaian dengan 3 (tiga) indikator sikap sabar yang dipraktikkan, yaitu; anak mengikuti petunjuk dengan baik, anak menyelesaikan tugasnya dengan tidak tergesa-gesa, dan sabar menunggu giliran. Peningkatan ini terjadi pada saat anak mampu mengikuti petunjuk permainan musik yang disampaikan guru, mampu memainkan tugas membunyikan alat musik sesuai tugas masing-masing, dan sabar memainkan alat musiknya sesuai gilirannya. Peningkatan yang signifikan ini dapat menjadi acuan bagi sekolah yang memiliki masalah dalam peningkatan sabar anak dengan permainan musik feeling band.

\section{UCAPAN TERIMAKASIH}

Terima kasih kami sampaikan kepada Kepala Sekolah dan guru Raudhatul Athfal Hasan Munadi I Banggle Kecamatan Beji Pasuruan yang telah memberikan izin dan bantuan kepada penulis untuk melakukan penelitian, sehingga selama proses pengumpuan data berjalan dengan lancar sebagaimana tujuan dan target yang diharapkan. 


\section{DAFTAR PUSTAKA}

Achroni, K. (2012). Mengoptimalkan Tumbuh Kembang Anak melalui Permaianan Tradisional. Javalitera.

Allen, J. W., \& Lalonde, C. E. (2020). Representations of natural environments, recurring characters and ways of living with the land in children's retellings of First Nations oral narratives. Early Childhood Research Quarterly, 53, 50-63. https://doi.org/10.1016/j.ecresq.2020.01.005

Bambang, S. (2008). Metode Pengembangan Fisik. Jakarta: Universitas Terbuka.

Bateman, A. (2020). Young children's affective stance through embodied displays of emotion during tellings. Text and Talk, 40(5), 643-668. https://doi.org/10.1515/text-2020-2077

Bates, A. (2019). Character education and the 'priority of recognition.' Cambridge Journal of Education, 49(6), 695-710. https:// doi.org/10.1080/0305764X.2019.1590529

Buroidah, H., Suwono, H., \& Fachrunnisa, R. (2021). Cultivating character as good citizen through problem solving infusion. In S. H., H. H., \& R. D. (Eds.), 4th International Conference on Mathematics and Science Education: Innovative Research in Science and Mathematics Education in the Disruptive Era, ICoMSE 2020 (Vol. 2330). American Institute of Physics Inc. https:// doi.org/10.1063/5.0043265

Chae, H., Cloninger, C. R., \& Lee, S. J. (2020). Effects of personality on the developmental trajectories of academic burnout among Korean medical students. PeerJ, 8. https://doi.org/10.7717/peerj.10362

Dwi Wardhani, J. (2016). Peran Permainan Musik Feeling Band Terhadap Perkembangan Emosi Anak. The Progressive and Fun Education.

Fachrurrazi, A. (2012). Strategi Pembelajaran anak Usia Dini. Gading Press.

Harun, Jaedun, A., Sudaryanti, \& Manaf, A. (2020). Dimensions of early childhood character education based on multicultural and community local wisdom. International Journal of Instruction, 13(2), 365-380. https:// doi.org/10.29333/iji.2020.13225a

Hasiana, I., \& Wirastania, A. (2017). Pengaruh Musik dalam Mengembangkan Kemampuan Mengenal Bilangan Siswa Kelompok A di TK Lintang Surabaya. Jurnal Obsesi : Jurnal Pendidikan Anak Usia Dini, 1(2), 131. https:/ / doi.org/10.31004/obsesi.v1i2.25

Kamtini. (2005). Bermain Melalui Gerak dan Lagu di Taman Kanak-kanak. Departemen Pendidikan Nasional.

M, Forgeard., E, Winner., A, Norton., G, S. (2008). Practicing a Musical Instrument in Childhood is Associated with Enhanced Verbal Ability and Nonverbal Reasoning. PLoS ONE, 10, 1-8. https:/ / doi.org/10.1371/journal.pone.0003566

Meissner, H., \& Timmers, R. (2020). Young Musicians' Learning of Expressive Performance: The Importance of Dialogic Teaching and Modeling. Frontiers in Education, 5. https://doi.org/10.3389/feduc.2020.00011

Nixon May, B. (2013). Public School Early Childhood Music Education: Challenges and Solutions. General Music Today, 27(1), 40-44. https://doi.org/10.1177/1048371313494783

Pakerti, Widia, D. (2009). Metode Pengembangan Sosial Emosional. Universitas Terbuka.

Pembinaan AUD, D. (2015). Pedoman Penanaman Sikap Pendidikan Anak Usia Dini. Direktorat PAUD.

Piquer, M. P., Villalobos, J. V, Albarracín, J. D. H., \& Fayos, I. C. (2020). Pedagogy with character: Approach to the pedagogical discipline as a field of reflection of the subject of education from Ricoeur . Bajo Palabra, 24, 525-546. https://doi.org/10.15366/bp.2020.24.026

Priyanti, Iin dan Setyowati, N. (2015). Optimalisasi Kecerdasan Emosi Melalui Musik Feeling Band Pada Anak Usia Dini. Jurnal Care, Vol. 3 no.1.

Przybylska, Anna., Z. (2018). Functions of Music That Support A Child's Development. Konteksty Pedagogiczne, 10, 61-79.

Sanjaya, W. (2011). Penelitian Tindakan Kelas. Kencana. 
Supeni, S., Ersta, L., Handini, O., \& Yusuf. (2020). Moral values of the javanese traditional game songs to strengthen character education at elementary schools in Surakarta. International Journal of Innovation, Creativity and Change, 12(11), 57-70.

Supeni, S., Hakim, L., \& Jumintono. (2019). Strengthening character education of early childhood through javanese traditional game dakon. International Journal of Recent Technology and Engineering, 7(6), 243-249.

Suyadi. (2010). Psikologi Belajar PAUD. Pustaka Insan Madani.

Suyanto, A. (2017). Pendidikan Anak Usia Dini. PT. Bumi Aksara.

Tholee, M. (2017). Ayo Berkreasi Doodle. Erlangga For Kids.

Treacy, D. S., \& Westerlund, H. (2019). Shaping imagined communities through music: Lessons from the School Song practice in Nepal. International Journal of Music Education, 37(4), 512-523. https:// doi.org/10.1177/0255761419850251

Vuorinen, K., Pessi, A. B., \& Uusitalo, L. (2021). Nourishing Compassion in Finnish Kindergarten Head Teachers: How Character Strength Training Influences Teachers' Other-Oriented Behavior. Early Childhood Education Journal, 49(2), 163-176. https://doi.org/10.1007/s10643-020-01058-0

Wahyuni, P. L. (2014). Upaya Meningkatkan Kemampuan Mengekspresikan Emosi Dasar melalui Permaianan Musik Feeling Band di. E-Print UNY. 